\title{
Knowledge, Attitude and Practice Towards COVID-19 Among People in Adiyaman, Turkey
}

\author{
Türkiye'nin Adıyaman Ilinde Insanların COVID-19 Salgınına Yönelik Bilgi, Tutum ve Uygulamaları
}

\author{
Emel Dundar', Ferit Kaya², Edibe Pirincci ${ }^{3}$ \\ ${ }^{1}$ Department of Family Medicine; ${ }^{2}$ Department of Public Health, Adiyaman University, Adiyaman; ${ }^{3}$ Department of Public Health, \\ Firat University, Elazig, Turkey
}

\begin{abstract}
Aim: This study was conducted to examine the knowledge, attitude and practices of individuals aged 18 and over towards one of the coronavirus outbreak COVID-19.

Material and Method: This cross-sectional study was carried out by applying a questionnaire to individuals who were registered to a family medicine unit in Adiyaman between 12 May and 10 July. The study population consists of 1842 people registered in the family physician unit. With 95\% confidence interval, 50\% prevalence, 0.5 margin of error, the number of people to be sampled was calculated as 255. The questionnaire was applied through face to face interviews. Averages were given with standard deviations. $\chi^{2}$ and t test were used as statistical analysis method. The $p<0.05$ was considered significant.
\end{abstract}

Results: The average age of participants included in the study was $39.92 \pm 13.52$ years and $63.0 \%$ were women. $84.3 \%$ were married. The mean knowledge score of the participants was found to be 5.68 1.71. In our study, the mean knowledge score was significantly higher in men, employees, and those with an associate degree or above $(p<0.05)$. The average attitude score of the participants was $2.40 \pm 0.78$, and mean practice score was $12.17 \pm 1.17$. The most known symptom in information questions was fever. If vaccination is available, $84.7 \%$ wanted to get vaccinated.

Conclusion: The mean score of knowledge, attitude and practice of individuals about COVID-19 was lower than expected. The mean score and attitude mean score were significantly higher in men. Therefore training programs should be planned to increase the knowledge level, positive attitudes and good practices of individuals in the struggle against COVID-19.

Key words: COVID-19; attitude; practice; outbreak

\section{ÖZET}

Amaç: Bu çalıșma 18 yaș ve üzeri bireylerin koronavirüs grubundan olan COVID-19 salgınına karșı bilgi, tutum ve uygulamalarını incelemek amacıyla yapılmıștır.

Materyal ve Metot: Kesitsel tipte olan bu çalıșma 12 Mayıs 2020-10 Haziran 2020 tarihleri arasında Adıyaman ilinde bir Aile Hekimliği Birimine kayıtı olan bireylere anket formu uygulanarak yapılmıștır. Aile Hekimliği Birimine kayıtı olan 1842 kiși çalıșmanın evrenini olușturmaktadır. \%95 güven aralığı, \%50 prevalans, 0,5 hata payı ile örnekleme alınacak kiși sayısı 255 olarak hesaplanmıștır. Anket formu yüz yüze görüșmeler yapılarak uygulanmıștır. Ortalamalar standart sapmalar ile birlikte verilmiștir. İstatistiksel analiz yöntemi olarak $X^{2}$ ve t testi ve kullanılmıștır. $P<0,05$ anlamlı olarak kabul edilmiștir.

Bulgular: Çalıșmaya dahil edilen katılımcıların yaș ortalaması 39,92 $\pm 13,52$ yıl olup, \%63,0'ı kadındır. \%84,3'ü ise evliydi.

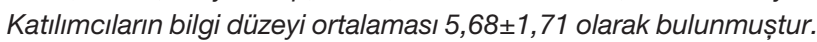
Çalıșmamızda bilgi puan ortalaması erkeklerde, çalıșanlarda ve ön lisans ve üzeri eğitim seviyesine sahip olanlarda anlamlı olarak daha yüksekti $(p<0,05)$. Katılımcıların tutum puanı ortalaması 2,40 $\pm 0,78$,

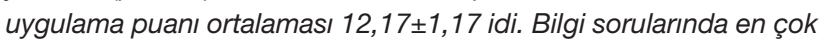
bilinen semptom atești. Așı olması durumunda \%84,7'si așı yaptırmak istiyordu.

Sonuç: Bireylerin COVID-19 hakkında bilgi düzeyi, tutum ve uygulamaları beklenenden düșüktü. Erkeklerde bilgi puan ortalaması ve tutum puan ortalaması anlamlı olarak daha yüksekti. Bu yüzden bireylerin COVID-19 ile mücadelede bilgi düzeyini, olumlu tutum ve uygulamalarını artıracak eğitimler yapılmalıdır.

Anahtar kelimeler: COVID-19; tutum; uygulama; salgın

IIetișim/Contact: Ferit Kaya, Department of Public Health, Adiyaman University, Adiyaman, Turkey • Tel: 05161642403 • E-mail:drferitkaya83@gmail.com • Geliș/Received:20.08.2020 • Kabul/Accepted: 17.05.2021

ORCID: Emel Dündar, 0000-0002-7223-7950 • Ferit Kaya, 0000-0002-0261-6293 • Edibe Pirinççi, 0000-0002-1344-4562 


\section{Introduction}

Coronaviruses are enveloped, positive single-stranded RNA viruses that infect both animals and humans ${ }^{1}$. Human infections are known to cause diseases ranging from the common cold to the Middle East Respiratory Syndrome (MERS) and Severe Acute Respiratory Syndrome (SARS). The new coronavirus (SARS-CoV-2) was detected first time with a case report in Wuhan city China in December 2019 and causing COVID-19 disease ${ }^{2}$. Detailed researches have revealed that SARS-CoV transmitted to people from Musk cats in China in 2002 and MERS-CoV from dromedary camels in Saudi Arabia in 2012. The animal source of SARS-CoV-2 has not been identified yet. It is emphasized that some of the first human infections were caused by a live animal market in China ${ }^{3}$. Studies to date show that the virus causing COVID-19 is mainly transmitted through respiratory droplets ${ }^{2}$.

The confirmed cases of COVID-19 varied from mild symptoms to severe disease conditions and death. Symptoms can include fever, cough, and shortness of breath. The Centers for Disease Control and Prevention (CDC) believe that symptoms of COVID-19 may appear 2 to 14 days after exposure. This information is based on the incubation time of the MERS-CoV virus previously determined ${ }^{4}$. Standard recommendations to prevent the spread of infection includes regular hand washing, maintaining the physical distance at least 1 meter, avoiding touching eye, mouth and nose and respiratory hygiene ${ }^{2}$.

Following the advice of the Emergency Committee on January 30 2020, World Health Organization General Director has declared the outbreak of novel coronavirus (2019-nCoV) a Public Health Emergency of International Concern 5 . World Health Organization General Director stated in media briefing on 11 March 2020 that COVID-19 could be described as a pandemic $^{6}$. At the Situation Report-158, published by WHO on 26 June 2020, 9473214 cases and 484249 deaths was reported worldwide 7 .

It is thought that the knowledge, attitude and practices of the public have an important effect on taking preventive measures and closing the gap in providing health information. Weak attitudes and bad practices related to the information gap, has a negative effect on disease prevention and control and contributes to an increased risk of infection during mass meetings ${ }^{8}$.
The COVID-19 pandemic, like other pandemics, causes significant increases in morbidity and mortality, damaging the economy through many channels. It causes individual practice changes, such as fearful avoidance from workplaces and other public gathering areas. It causes social and political negative effects?

This study was conducted to examine the knowledge, attitude and practice of individuals aged 18 and over against the COVID-19 outbreak.

\section{Material and Method}

This study, which is a cross-sectional type, was carried out between the dates of 12 May and 10 July 2020 in the population of family medicine unit-81 of Adiyaman, aged 18 and over. According to the data of Adiyaman Provincial Health Directorate the registered 1842 people aged 18 and over in the family medicine unit- 81 constituted the study population of the study. In determining the number of people to be sampled, the formula $\mathrm{n}=\mathrm{Nt}^{2} \mathrm{pq} / \mathrm{d}^{2}(\mathrm{~N}-1)+\mathrm{t}^{2} \mathrm{pq}$ was used and the number of people to be sampled was calculated as 254 with $95 \%$ confidence interval, $50 \%$ prevalence and $0.5 \%$ deviation.

The questionnaire was prepared after literature review $^{8,10}$. The questionnaire had 8 questions regarding knowledge, 5 questions regarding attitude and 7 questions regarding practices. Assessment was made by giving one point to each correct answer about knowledge and attitude, and giving 2 points to always option, 1 point to sometimes option and 0 point to never option about practices Knowledge questions were evaluated as total 8 points, attitude questions were evaluated as total 5 points and practices related questions were evaluated as total 14 points.

Inclusion criteria were determined as being 18 years of age and over and accepting to participate the study. People included in study was 254 , determined by using random numbers table from the study population. Then, people were called by phone and invited to the family health center. Participation in the survey was voluntary, after giving information and signing the consent form it was applied in the waiting area in front of family health center outdoor. The questionnaires were applied by face-to-face interviews by the responsible researcher, after obtaining the ethics committee approval dated 20.04.2020 no: 2020/5 from the Adiyaman University Ethics Committee with permission of ministry of health. 
Table 1. Some socio-demographic characteristics of participants and the distribution of the resources of the knowledge about outbreak

\begin{tabular}{llcc}
\hline Variables & & Numbers & Percentage \\
\hline Age & $\leq 30$ & 68 & 26.8 \\
& $>30$ & 186 & 73.2 \\
\hline Gender & Male & 94 & 37.0 \\
& Female & 160 & 63.0 \\
\hline Maritial status & Married & 214 & 84.3 \\
& Single & 40 & 15.7 \\
\hline Education level & Uneducated & 23 & 9.1 \\
& Primary school & 67 & 26.4 \\
& Secondary school & 44 & 17.3 \\
& High school & 48 & 18.9 \\
& Associate degree/university & 72 & 28.3 \\
\hline Employment & Yes & 85 & 33.5 \\
& No & 169 & 66.5 \\
\hline Source of & Television & 224 & 88.2 \\
information & Internet & 24 & 9.4 \\
\hline
\end{tabular}

The data obtained were recorded in the SPSS 22 program, error checks, tables and statistical analyzes were made through this program. Averages are given with standard deviations. $\chi^{2}$ and t test were used as statistical analysis method. " $\mathrm{p}<0.05$ " was considered significant.

\section{Results}

The average age of the participants is $39.92 \pm 13.52$ years and $63.0 \%$ are women. Of them $84.3 \%$ are married. Of the participants $28.3 \%$ are associate degree-university graduates and $66.5 \%$ do not work in any job (Table 1 ). In our study, the frequency of those who heard that the outbreak was $97.6 \%$, the frequency of those who knew the name of the outbreak was $81.5 \%$, the frequency of those who knew the city where the outbreak first appeared was $35.0 \%$, the frequency of those who knew the incubation period was $47.2 \%$, the frequency of those who knew that it could be transmitted from person to person was $95.7 \%$ and the frequency of those who knew the possibility of transmission from animal to person was $71.3 \%$. The majority of the participants $(88.2 \%)$ stated television broadcasts as a source of information (Table 2).

When the answers of the participants to the questions about the attitudes are evaluated; the frequency of those who considered to be dangerous was $96.9 \%$, the frequency of those who thought that the epidemic was preventable was $68.1 \%$, the frequency of those who thought that education might decrease the probability of transmission $77.6 \%$, the frequency of those who thought that it would affect the economy negatively was $92.9 \%$ and the frequency of those who would like to have vaccination was $84.7 \%$ (Table 3 ).

In order to measure the practices of the participants towards preventing the epidemic, the frequency of practice was questioned as "always, sometimes, never" options. "Always" option was preferred the most in all questions posed. This frequency is $94.1 \%$ for hand washing practice, $49.6 \%$ for physical distancing practice, $46.5 \%$ for avoiding touching the eyes, mouth and nose, $87.8 \%$ for closing the mouth and nose while coughing and sneezing, $96.4 \%$ for the not using the napkin again, $91.0 \%$ for mask-wearing practice and $79.5 \%$ for avoiding consumption of raw or undercooked foods (Table 4).

In our study, the mean knowledge score was significantly higher in men, employees, and those with an associate degree or above $(\mathrm{p}<0.05)$. Although not significant, it was high in the group over 30 years old and those who showed internet use as a source of information. In our study, the mean attitude score was high, although not significant, in men, employees, over 30 years of age, and those who showed internet use as a source of information. In our study, the mean score of practice was high in women, those who do not work in any job, those with an associate degree and above education level, in the group over 30 years of age and those who showed internet use as a source of information (Table 5).

\section{Discussion}

The main source of information about outbreak is television in our study. Its observed in a similar study that main source was television ${ }^{10}$ and in some others it was internet $^{11,12}$. It is thought that these different results may result from the socio-economic and socio-cultural differences of the residents of the country.

When the responses given to information questions are analyzed according to gender, the level of knowledge of men is significantly higher in "which city the outbreak originated" and "the incubation period" questions. In other information questions, although the answers given by men are high, they are not significant. The most known symptom in both sexes was fever. This has been evaluated as a parallel result of the fever being the most common initial symptom ${ }^{13}$. 
Table 2. Answers given by participants to information questions about the outbreak and their distribution by gender

\begin{tabular}{|c|c|c|c|c|c|c|c|c|}
\hline \multirow{2}{*}{ Knowledge questions } & & \multicolumn{2}{|c|}{ Total } & \multicolumn{2}{|c|}{ Male } & \multicolumn{2}{|c|}{ Female } & \multirow[b]{2}{*}{ Test and $p$ value } \\
\hline & & $\mathrm{n}$ & $\%$ & $\mathrm{n}$ & $\%$ & $\mathrm{n}$ & $\%$ & \\
\hline \multirow[t]{2}{*}{ Name of outbreak } & Knows & 248 & 97.6 & 81 & 86.2 & 127 & 79.4 & $\begin{array}{c}X^{2}=1.844 \\
p>0.05\end{array}$ \\
\hline & Doesn't know & 6 & 2.4 & 13 & 13.8 & 33 & 20.6 & \\
\hline \multirow[t]{2}{*}{ Which city outberak originated? } & Knows & 89 & 35 & 48 & 51.1 & 41 & 25.6 & $\begin{array}{c}X^{2}=16.83 \\
p<0.001\end{array}$ \\
\hline & Doesn't know & 165 & 65 & 46 & 48.9 & 119 & 74.4 & \\
\hline \multirow[t]{2}{*}{ Fever } & Yes & 226 & 89 & 86 & 91.5 & 140 & 87.5 & $\begin{array}{c}X^{2}=0.961 \\
p>0.05\end{array}$ \\
\hline & No/no idea & 28 & 11 & 8 & 8.5 & 20 & 12.5 & \\
\hline \multirow[t]{2}{*}{ Cough } & Yes & 189 & 74.4 & 74 & 78.7 & 115 & 71.9 & $\begin{array}{c}X^{2}=1.458 \\
p>0.05\end{array}$ \\
\hline & No/no idea & 65 & 25.6 & 20 & 20.3 & 45 & 28.1 & \\
\hline \multirow[t]{2}{*}{ Breathing difficulties } & Yes & 189 & 74.4 & 71 & 75.5 & 118 & 73.8 & $\begin{array}{c}X^{2}=0.099 \\
p>0.05\end{array}$ \\
\hline & No/no idea & 65 & 25.6 & 23 & 24.5 & 42 & 26.3 & \\
\hline \multirow[t]{2}{*}{ Incubation period } & knows & 120 & 47.2 & 53 & 56.4 & 67 & 41.9 & $\begin{array}{c}X^{2}=5.000 \\
p<0.05\end{array}$ \\
\hline & Doesn't know & 134 & 52.8 & 41 & 43.6 & 93 & 58.1 & \\
\hline \multirow[t]{2}{*}{ Transmission from human to human } & Yes & 243 & 95.7 & 90 & 95.7 & 153 & 95.6 & $\begin{array}{c}X^{2}=0.002 \\
p>0.05\end{array}$ \\
\hline & No/no idea & 11 & 4.3 & 4 & 4.3 & 7 & 4.4 & \\
\hline \multirow[t]{2}{*}{ Transmission from snimal to human } & Yes & 181 & 71.3 & 71 & 75.5 & 110 & 68.8 & $\begin{aligned} X^{2} & =1.330 \\
p & >0.05\end{aligned}$ \\
\hline & No/no idea & 73 & 28.7 & 23 & 24.5 & 50 & 31.2 & \\
\hline Total knowledge score & Mean \pm SD & \multicolumn{2}{|c|}{$5.68 \pm 1.71$} & \multicolumn{2}{|c|}{$6.10 \pm 1.58$} & \multicolumn{2}{|c|}{$5.44 \pm 1.75$} & $\begin{array}{c}t=0.788 \\
p<0.05\end{array}$ \\
\hline
\end{tabular}

Table 3. Attitudes of participants towards the outbreak of COVID-19 and their distribution by gender

\begin{tabular}{|c|c|c|c|c|c|c|c|}
\hline & \multicolumn{2}{|c|}{ Total } & \multicolumn{2}{|c|}{ Male } & \multicolumn{2}{|c|}{ Female } & \multirow[b]{2}{*}{$\mathrm{p}$ value } \\
\hline & $\mathrm{n}$ & $\%$ & $\mathrm{n}$ & $\%$ & $\mathrm{n}$ & $\%$ & \\
\hline \multicolumn{8}{|l|}{ Is it dangerous? } \\
\hline Yes & 246 & 96.9 & 91 & 96.8 & 155 & 96.9 & $\begin{aligned} X^{2} & =0.001 \\
p & >0.05\end{aligned}$ \\
\hline No/no idea & 8 & 3.1 & 3 & 3.2 & 5 & 3.1 & \\
\hline \multicolumn{8}{|l|}{ Is it preventable? } \\
\hline Yes & 173 & 68.1 & 68 & 72.3 & 105 & 65.6 & $\begin{aligned} X^{2} & =1.229 \\
p & >0.05\end{aligned}$ \\
\hline No/no idea & 81 & 31.9 & 26 & 27.7 & 55 & 34.4 & \\
\hline \multicolumn{8}{|c|}{ Can be decreased by education? } \\
\hline Yes & 197 & 77.6 & 79 & 84 & 118 & 73.8 & $\begin{array}{c}X^{2}=3.604 \\
p>0.05\end{array}$ \\
\hline No/no idea & 57 & 22.4 & 15 & 16 & 42 & 26.2 & \\
\hline \multicolumn{8}{|c|}{ Does it effect world economics negatively? } \\
\hline Yes & 236 & 92.9 & 91 & 96.8 & 145 & 90.6 & $\begin{aligned} X^{2} & =3.438 \\
p & >0.05\end{aligned}$ \\
\hline No/no idea & 18 & 7.1 & 3 & 3.2 & 15 & 9.4 & \\
\hline \multicolumn{8}{|l|}{ Do you vaccinate if present? } \\
\hline Yes & 215 & 84.7 & 78 & 83 & 137 & 85.6 & $\begin{aligned} X^{2} & =0.319 \\
p & >0.05\end{aligned}$ \\
\hline No/no idea & 39 & 15.3 & 16 & 17 & 23 & 14.4 & \\
\hline Attitude score (mean \pm SD) & \multicolumn{2}{|c|}{$2.40 \pm 0.78$} & \multicolumn{2}{|c|}{$2.45 \pm 0.72$} & \multicolumn{2}{|c|}{$2.37 \pm 0.082$} & $\begin{array}{l}t=1.827 \\
p>0.05\end{array}$ \\
\hline
\end{tabular}


Tablo 4. Practices of participants towards preventing the COVID-19 outbreak

\begin{tabular}{|c|c|c|c|c|c|c|}
\hline \multirow[b]{2}{*}{ Practice questions } & \multicolumn{2}{|c|}{ Always } & \multicolumn{2}{|c|}{ Sometimes } & \multicolumn{2}{|c|}{ Never } \\
\hline & $\mathrm{n}$ & $\%$ & $\mathrm{n}$ & $\%$ & $\mathrm{n}$ & $\%$ \\
\hline Hand washing & 239 & 94.1 & 15 & 5.9 & 0 & 0 \\
\hline Social distancing & 126 & 49.6 & 111 & 43.7 & 17 & 6.7 \\
\hline Avoide touching eyes, mouth and nose & 118 & 46.5 & 111 & 43.7 & 25 & 9.8 \\
\hline Covering mouth when coughing and sneezing & 223 & 87.8 & 23 & 9.1 & 8 & 3.1 \\
\hline Not to use napkin again & 245 & 96.4 & 7 & 2.8 & 2 & 0.8 \\
\hline Wearing mask & 231 & 91 & 11 & 4.3 & 12 & 4.7 \\
\hline Avoid consuming raw or undercooked animal products & 202 & 79.5 & 47 & 18.5 & 5 & 2 \\
\hline
\end{tabular}

Tablo 5. Comparative evaluation of the participants' knowledge, attitude and practice scores

\begin{tabular}{|c|c|c|c|c|c|c|}
\hline & \multicolumn{2}{|c|}{ Knowledge } & \multicolumn{2}{|c|}{ Atitude } & \multicolumn{2}{|c|}{ Practices } \\
\hline & score & test & score & test & score & test \\
\hline \multicolumn{7}{|l|}{ Age } \\
\hline$\leq 30$ & $5.57 \pm 1.62$ & $t=0.136$ & $2.32 \pm 0.88$ & $\mathrm{t}=4.47$ & $12.00 \pm 1.59$ & $\mathrm{t}=1.119$ \\
\hline$>30$ & $5.73 \pm 1.75$ & $\mathrm{p}>0.05$ & $2.43 \pm 0.74$ & $p>0.05$ & $12.24 \pm 1.84$ & $p>0.05$ \\
\hline \multicolumn{7}{|l|}{ Gender } \\
\hline Male & $6.10 \pm 1.58$ & $t=0.788$ & $2.45 \pm 0.72$ & $t=1.827$ & $12.01 \pm 1.92$ & $t=1.585$ \\
\hline Female & $5.44 \pm 1.75$ & $\mathrm{p}<0.05$ & $2.37 \pm 0.82$ & $p>0.05$ & $12.27 \pm 1.68$ & $P>0.05$ \\
\hline \multicolumn{7}{|l|}{ Education } \\
\hline High school and below associate & $5.42 \pm 1.79$ & $\mathrm{t}=8.227$ & $2.40 \pm 0.79$ & $t=0.155$ & $12.13 \pm 1.87$ & $t=2.095$ \\
\hline Degree/university & $6.36 \pm 1.28$ & $\mathrm{p}<0.001$ & $2.40 \pm 0.78$ & $p>0.05$ & $12.27 \pm 1.50$ & $p>0.05$ \\
\hline \multicolumn{7}{|l|}{ Employment } \\
\hline Yes & $6.38 \pm 1.38$ & $t=3.597$ & $2.44 \pm 0.73$ & $t=1.510$ & $12.07 \pm 1.52$ & $t=1.962$ \\
\hline No & $5.33 \pm 1.76$ & $\mathrm{p}<0.001$ & $2.38 \pm 0.81$ & $p>0.05$ & $12.23 \pm 1.89$ & $p>0.05$ \\
\hline \multicolumn{7}{|l|}{ Source of information } \\
\hline Television & $5.74 \pm 1.61$ & $\mathrm{t}=2.061$ & $2.39 \pm 0.79$ & $\mathrm{t}=0.00$ & $12.23 \pm 1.71$ & $t=0.112$ \\
\hline Internet & $6.16 \pm 1.27$ & $p>0.05$ & $2.41 \pm 0.77$ & $p>0.05$ & $12.08 \pm 1.66$ & $p>0.05$ \\
\hline Total score & \multicolumn{2}{|c|}{$5.68 \pm 1.71$} & \multicolumn{2}{|c|}{$2.40 \pm 0.78$} & \multicolumn{2}{|c|}{$12.17 \pm 1.17$} \\
\hline
\end{tabular}

When questioned whether or not they will get vaccinated if vaccine is available, the frequency of participants rejecting vaccination or unsure about getting vaccinated was $15.3 \%$. In other study done by an online survey both in Turkey and UK, 34.0\% of the participants in Turkey was rejecting vaccination or unsure about getting vaccinated. It has been thought that a relatively high level of vaccination desire may result from the difference of the study population. In the study analyzing 38 studies which are examining attitudes towards vaccines, concerns about reliability and side effects were among the primary causes of hesitation against vaccines ${ }^{15}$. In another study, it was observed that even health care professionals was unsure about vaccination, $35 \%$ of healthcare professionals in study population preferred to wait for extensive community experiences before recommending a new vaccine ${ }^{16}$.

When the average age and the information score were compared, the mean score below the age of 30 was found to be lower but it was not significant. Similar results were obtained in a study of COVID-19 for healthcare workers and in another study with MERS for healthcare workers ${ }^{12,17}$. When the knowledge score was examined according to gender, it was observed that the information score of men was significantly higher than women $(p<0.05)$. In a study conducted in China, it was observed that women had significantly higher knowledge ${ }^{18}$. In two different studies conducted for health workers with MERS was observed to have a higher level of knowledge of the male ${ }^{19,11}$. Considering 
these different results, these result in our study was thought to be result of the male dominant culture in Turkey.

The knowledge score of associate degree/university graduates was significantly higher than that of high school and below graduates $(\mathrm{p}<0.01)$. A similar study in Covid-19 in China showed a parallel relationship between education level and knowledge level ${ }^{18}$. And in a study conducted in Northern Thailand, the level of knowledge was found higher in those who had a higher education level ${ }^{10}$.

The knowledge score was higher in employees than the ones who are not working in any job $(\mathrm{p}<0.001)$. In a similar study, the knowledge score was higher among the employees ${ }^{18}$. It was thought that this result obtained in the employees may be due to the fact that these people feel more at risk due to the fact that they encounter other people more and therefore they need to be informed about the epidemic.

The knowledge score of the participants who stated the internet as the source of information was higher than those who stated the television as the source of information, but it was not significant. In a similar study, when the information source and the average score were compared, the knowledge score was found to be higher in those who stated internet as source of information ${ }^{10}$.

It was observed that participants over the age of 30 had a higher attitude score but it was not significant. As similar, in two other studies related to COVID-19, under 30 years of age had the lowest attitude score average ${ }^{18,10}$.

In the attitude questions posed to the participants; men have a higher score than women. In a similar study conducted by Srichan et al. ${ }^{10}$, the frequency of having adequate attitude scores in women was higher than men, but when the knowledge score was examined in the same study, it was noticed that women had higher knowledge score than men. The results in two similar studies showing the relationship between the frequency of knowledge and positive attitude were thought to support this result ${ }^{18,20}$. Men thought more than women that it would have a negative impact on the economy. It is thought that this attitude about the effects on the economy may result from the higher economic responsibilities of men.

The attitude score of employees is higher than those who do not work in any job. In a study conducted in
China, when the occupational groups and attitude scores were analyzed comparatively, it was observed that those who did not work had a lower score than the employees ${ }^{18}$. Our study is compatible with the literature.

In our study, there was no difference in terms of attitude score among those using the internet or television as a source of information. In a similar study conducted in Northern Thailand, the attitude score of those who use television broadcasts as an information source was found to be higher ${ }^{10}$. The difference between studies may have resulted from the difference between the sample groups.

When the practice score average was examined according to age groups, it was higher in those over 30 but not significant. When the similar study examined, it was seen that participants younger than age of 30 had the lowest average ${ }^{18}$.

When the practices that should be done for protection from infection examined, it was observed that women had higher practice scores, although not significant. When similar studies were examined, it was seen that women had higher practice scores for protection from infection ${ }^{10}$.

When the practices are analyzed in comparison with the education level, it is seen that associate degree/university graduates have higher mean scores in practice scores, although not significant. When the practices were examined in two studies on influenza pandemics, the relationship between education level and practice scores attracted attention ${ }^{21,22}$.

As a result, participants knowledge of COVID-19 was moderate and their attitudes were positive, and the knowledge and attitudes of men were higher than women. The most known symptom in knowledge questions was fever. If there is vaccination, $84.7 \%$ wanted to get vaccinated. Practice score was positive and no difference was found between the genders. Therefore training programs, that will increase the level of knowledge, positive attitudes and practices of individuals in the struggle against COVID-19 should be planned.

\section{References}

1. Velavan TP, Meyer CD. The COVID-19 epidemic. Trop Med Int Heal 2020;100:278-80.

2. WHO. COVID-19, https://www.who.int/news-room/q-adetail/q-a-coronaviruses/;2020 [accessed 15.03.20]. 
3. WHO. Coronavirus, https.//ww.who.int/health-topics/ coronavirus/;2020 [accessed 18.02.20].

4. CDC. Symptoms, https://www.cdc.gov/coronavirus/2019ncov/symptoms-testing/symptoms.html/;2020 [accessed 15.03.20].

5. WHO. Statement on the second meeting of the International Health Regulations (2005) Emergency Committee regarding the outbreak of novel coronavirus (2019-nCoV), https:// www.who.int/news-room/detail/30-01-2020-statement-onthe-second-meeting-of-the-international-health-regulations(2005)-emergency-committee-regarding-the-outbreak-of-novel-coronavirus-(2019-ncov)/;2020 [accessed:15.03.20].

6. WHO. Emergencies, https://www.who.int/emergencies/ diseases/novel-coronavirus-2019/events-as-they-happen/;2020 [accessed 1.03.20].

7. WHO. Coronavirus Disease (COVID-19) Situation Reports, https://www.who.int/emergencies/diseases/novelcoronavirus-2019/situation-reports/;2020 [accessed 27.06.20].

8. Goni MD, Hasan H, Naing NN, Arfah N, Deris ZZ, Arifin WN et al. Assessment of knowledge, attitude and practice towards prevention of respiratory tract infections among hajj and umrah pilgrims from Malaysia in 2018. Int J Environ Res Public Health 2019;16(22):1-11.

9. NCBI. Pandemics:risks, impacts, and mitigation, https:// www.ncbi.nlm.nih.gov/books/NBK525302/;2020 [accessed 15.03.20].

10. Srichan P, Apidechkul T, Tamornpark R, Yeemard F, Khunthason S, Kitchanapaiboon S et al. Knowledge, Attitude and Preparedness to respond to the 2019 Novel Coronavirus (COVID-19) among the bordered population of northern Thailand in the early period of the outbreak:A cross-sectional study. SSRN Electronic Journal 2020:SSRN 3546046.

11. Khan MU, Shah S, Ahmad A, Fatokun O. Knowledge and attitude of healthcare workers about middle east respiratory syndrome in multispecialty hospitals of Qassim, Saudi Arabia. BMC Public Health 2014;14(1):1-7.

12. Nour MO, Babilghith AO, Natto HA, Al-Amin FO, Alawneh SM. Knowledge, attitude and practices of healthcare providers towards MERS-CoV infection at Makkah hospitals KSA. IRJMMS 2015;3:103-12.
13. Chen J, Qi T, Liu L, Yun L, Qian Z, Li T et al. Clinical progression of patients with COVID-19 in Shanghai, China. J. Infect 2020;80(5):1-6.

14. Sağlık Bakanlığı. Sağlık İstatistikleri Yıllığ 2018 , https:// dosyasb.saglik.gov.tr/Eklenti/36134,siy2018trpdf.pdf ?0/;2020 [accessed 19.04.2020].

15. Yaqub O, Castle-Clarke S, Sevdalis N, Chataway J. Attitudes to vaccination:a critical review. Soc Sci Med 2014;112:1-11.

16. Bakhache P, Rodrigo C, Davie S, Ahuja A, Sudavar B Crudup T et al. Health care providers' and parents' attitudes toward administration of new infant vaccines-A multinational survey. Eur J Pediatr 2013;172 (4):485-92.

17. Huynh H, Nguyen TN, Tran VK, Vo KN, Vo VT, Pham LA. Knowledge and attitude toward COVID-19 among healthcare workers at district 2 Hospital, Ho Chi Minh City. Asian Pac J Trop Med 2020;13:6-11.

18. Zhong BL, Luo W, Li HM, Zhang QQ, Liu XG, Li WT et al. Knowledge, attitudes, and practices towards COVID-19 among Chinese residents during the rapid rise period of the COVID-19 outbreak: a quick online cross-sectional survey. Int J Biol Sci 2020;16(10):1745-52.

19. Albarrak AI, Mohammed R, Elayan AA, Fawaz FA, Masry MA, Shammari MA et al. Middle East Respiratory Syndrome (MERS): Comparing the knowledge, attitude and practices of different health care workers. J Infect Public Health 2019;617:6-13.

20. Aziz MM, Abd El-Megeed HS, Abd Ellatif MAM. Pre-travel health seeking practices of Umrah pilgrims departing from Assiut International Airport Egypt. Travel Med Infect Dis 2018;23:72-6.

21. Balkhy HH, Abolfotouh MA, Al-hathlool RH, Al-jumah MA. Awareness, attitudes, and practices related to the swine influenza pandemic among the Saudi public. BMC 2010;10(42:1-7.

22. Sadique MA, Edmunds WJ, Smith RD, Meerding WJ, Zwarts O, Brugs J. et al. Precautionary behavior in response to perceived threat of pandemic influenza. Emerg. Infect. Dis 2007;13(9):1307-13. 